\title{
USG guided central venous cannulation in ICU: a comparision with conventional approach
}

\author{
A Agarwal $^{1 *}$, DK Singh ${ }^{2}, M$ Tripathi $^{1}$ \\ From 10th WINFOCUS World Congress on Ultrasound in Emergency and Critical Care \\ Kuala Lumpur, Malaysia. 16-19 November 2014
}

\section{Background}

The introduction of portable ultrasonography machines into clinical practice has found widespread usage in the ICUs. They are handy and serve as point of care resource.

Among the common usage in ICU include

- Central venous cannulation

- Assessment of the cause of abdominal distension

- DVT assessment

- Identification of pericardial tamponade

- Valvular pathology \& LV function

This saves time and is also safer as it avoids shifting of critically ill patients to other departments.

\section{Objectives}

We performed a study to compare USG \& conventional techniques of CVC.

\section{Material and methods}

We performed the study in 60 patients over a period of 3 months. A portable ultrasound machine (Sonosite Micromax) was used with a probe of $7.5 \mathrm{MHz}$ frequency. Cannulation was done using real time imaging. In the conventional method cannulation was done using the landmark approach. The parameters studied included

- Time from completion of draping to successful insertion of needle.

- Number of attempts required.

- Incidence of complications.

\footnotetext{
* Correspondence: drankit80@gmail.com

'Department of Anesthesiology \& Critical Care, All India Institute of Medical Sciences Rishikesh, India

Full list of author information is available at the end of the article
}

\section{Results}

We found that USG approach took lesser time, required lesser attempts and had lower incidence of complications.

\section{Conclusion}

USG guided CVC is easier, quicker \& safer than landmark approach.

\section{Authors' details}

${ }^{1}$ Department of Anesthesiology \& Critical Care, All India Institute of Medical Sciences Rishikesh, India. ${ }^{2}$ Department of Anesthesiology \& Critical Care, Banaras Hindu University, Varanasi, India.

Published: 9 March 2015

doi:10.1186/2036-7902-7-S1-A1

Cite this article as: Agarwal et al:: USG guided central venous

cannulation in ICU: a comparision with conventional approach. Critical Ultrasound Journal 2015 7(Suppl 1):A1.

\section{SpringerOpen $^{\circ}$}

(c) 2015 Agarwal et al; licensee Springer. This is an Open Access article distributed under the terms of the Creative Commons Attribution License (http://creativecommons.org/licenses/by/4.0), which permits unrestricted use, distribution, and reproduction in any medium, provided the original work is properly cited.
Submit your manuscript to a SpringerOpen ${ }^{\circ}$ journal and benefit from:

- Convenient online submission

- Rigorous peer review

- Immediate publication on acceptance

- Open access: articles freely available online

- High visibility within the field

Retaining the copyright to your article

Submit your next manuscript at $>$ springeropen.com 